The Philosophy of Food 



\title{
The Philosophy of Food
}

\author{
Edited by \\ David M. Kaplan
}

曲

UNIVERSITY OF CALIFORNIA PRESS

Berkeley Los Angeles London 
University of California Press, one of the most distinguished university presses in the United States, enriches lives around the world by advancing scholarship in the humanities, social sciences, and natural sciences. Its activities are supported by the UC Press Foundation and by philanthropic contributions from individuals and institutions. For more information, visit www.ucpress.edu.

University of California Press

Berkeley and Los Angeles, California

University of California Press, Ltd.

London, England

() 2012 by The Regents of the University of California

Library of Congress Cataloging-in-Publication Data

The philosophy of food / edited by David M. Kaplan.

p. $\mathrm{cm}$.

Includes bibliographical references and index.

ISBN 978-0-520-26933-o (cloth : alk. paper)

ISBN 978-0-520-26934-7 (pbk. : alk. paper)

1. Food. I. Kaplan, David M.

$\mathrm{TX}_{357 .} \mathrm{P}_{53} 2011$

641.3-dc23

2011032946

Manufactured in the United States of America

$\begin{array}{ccccccccccc}20 & 19 & 18 & 17 & 16 & 15 & 14 & 13 & 12 & 11 \\ 10 & 9 & 8 & 7 & 6 & 5 & 4 & 3 & 2 & 1 & \end{array}$

In keeping with a commitment to support environmentally responsible and sustainable printing practices, UC Press has printed this book on Rolland Enviro10o, a 100\% post-consumer fiber paper that is FSC certified, deinked, processed chlorine-free, and manufactured with renewable biogas energy. It is acid-free and EcoLogo certified. 
Matt Margolin

(September 13, 1966-September 24, 2010) 
